\title{
Short Communication. Witch's Milk: Potential for Neonatal Diagnosis
}

\author{
GERTRUDE CASE BUEHRING ${ }^{(25)}$ \\ Department of Biomedical and Environmental Health Sciences, School of Public Health, University of California, \\ Berkeley, California, USA
}

\begin{abstract}
Summary
The study population comprised 106 infants ranging from 4 days to 19 wk old. Fluid (witch's milk) was obtained from the infants' breasts by manual expression. To measure volume, fluid was drawn into calibrated capillary pipettes. The frequency of obtaining witch's milk was $71 \%$ for all infants and $100 \%$ for infants less than 3 wk of age. It declined with increasing age. The median volume of fluid obtained was $20 \mu \mathrm{l}$ per sampling for all infants and $55 \mu \mathrm{l}$ for babies $\leq 3$ wk of age. Frequency of witch's milk recovery was significantly related to the degree of manual pressure applied but was not related to sex of the baby.
\end{abstract}

\section{Speculation}

Because witch's milk was present in all babies less than 3 wk of age, in a volume suitable for microbiology and microchemistry tests, it might prove a useful body fluid for neonatal diagnostic tests. Analyses of witch's milk for microorganisms and levels of indicator chemicals would be a fertile area for future research.

\section{INTRODUCTION}

The breasts of newborns secrete milk in parallel response to the hormonal stimuli that prepare the mother's breasts for lactation (10). This secretion of infants, known as witch's milk was first described in 1686 (2). Its vivid name apparently arose from the belief that, if the secretion were not promptly and repeatedly expressed from the baby, witches would suckle the infant's breasts and leave their curse or mark (7). During the late nineteenth and early twentieth centuries, witch's milk was studied by several investigators in an effort to understand the mechanism of its secretion $(3,4,6,11-13)$. Currently, the pediatric clinician is advised that production of witch's milk is a phenomenon "requiring observation but no interference" (18). The possibility for practical use of this body fluid, e.g., for diagnosis, has been completely overlooked. For example, are substances currently assayed in blood or urine of neonates also present in witch's milk? Does witch's milk contain any substances in uniquely high concentrations which might allow development of new diagnostic chemistry tests or increase the sensitivity of established tests? As a first step in exploring these possibilities, this study was designed to determine: (1) whether witch's milk could be recovered from neonates with high enough frequency to warrant diagnostic use; and (2) whether volumes recovered were sufficient for diagnostic tests.

\section{MATERIALS AND METHODS}

Acquisition of experimental subjects. Parents volunteered their babies as subjects in response to personal referrals or communications through women's organizations and medical units, and provided informed consent complying with federal standards (5). The University of California, Berkeley, Committee for the Protection of Human Subjects approved protocol for subject use.
Medical history. Medical history recorded age, race, sex, and type of feeding (breast or bottle).

Breast fluid collection. Fluid was obtained from the infants' breasts by manual expression (Fig. 1), the force of which I subjectively estimated as light, medium, or hard. For consistency, I sampled all babies and tried to apply a uniform range of pressure (medium). To measure volume, fluid was drawn into calibrated capillary pipettes of 10,25 and $50 \mu \mathrm{l}$ volumes (wiretrol, Drummond Scientific Co., Broomall, PA) or serologic pipettes marked in 0.1 $\mathrm{ml}$ gradations (7506, Falcon Plastics, Oxnard, CA).

Statistical analysis. Although some babies were sampled repeatedly, only the result of the first sampling was used for statistical analysis of frequency distribution in the total population. Results of subsequent samplings of a subpopulation were analyzed separately. Significance of frequency distribution variables was analyzed by the chi-square test.

\section{RESULTS}

Composition of study population. The study population comprised 106 infants ranging from 4 days to 19 wk old. Eighteen were $\leq 3$ wk of age, 37 were 4-8 wk old, and the remainder were older than 8 wk. Fifty-two were male and 54 were female. Racial distribution was 97 Caucasian, 6 Asian, and 3 Black. Noncaucasian donors were not represented in sufficient number to permit using race as a variable in statistical analysis. It was also impossible to use type of feeding as a variable in analysis, because only $3 /$ $106(3 \%)$ of all subjects were bottle fed.

Obtaining fluid. I obtained fluid from 75/106 (71\%) of all infants. The gentle manual expression used rarely resulted in crying. Most babies who were asleep when sampled did not even wake up. Parents never reported adverse consequences of witch's milk sampling. Pressure of the manual expression was limited by the baby's and/or parent's reaction. Frequency of witch's milk recovery was significantly related to the degree of manual pressure applied: light, 6/16 (38\%); medium, 65/86 (76\%); and hard, 4/4 (100\%).

Fluid was obtained from 4/6 Asians, 2/3 Blacks, and 69/97 Caucasians. Recovery of fluid was not significantly related to sex of the baby, but was related to age (Fig. 2). The frequency of obtaining fluid was $100 \%$ for infants less than 3 wk old and declined with increasing age. The oldest baby from whom fluid could be obtained was 19 wk of age.

A subpopulation of nine infants was sampled at weekly intervals for periods of from 4-25 wk. Breasts were effectively emptied at each sampling, yet milk was obtainable at subsequent samplings. One of these infants produced milk until 24 wk of age. The frequency of obtaining fluid was consistently higher for these infants throughout the test period (Fig. 2).

Volume of fluid obtained. The median volume of fluid obtained at first sampling was $20 \mu \mathrm{l}$ (both breasts) with a range $1-400 \mu \mathrm{l}$ and $60 \%$ of values lying in the middle $90 \%$ of the range. For babies $\leq 3 \mathrm{wk}$ old, median volume was $55 \mu \mathrm{l}$ with a range $10-400$ $\mu \mathrm{l}$, and $82 \%$ of values lying in the middle $90 \%$ of the range. The largest specimen per breast obtained from babies sampled repeat- 


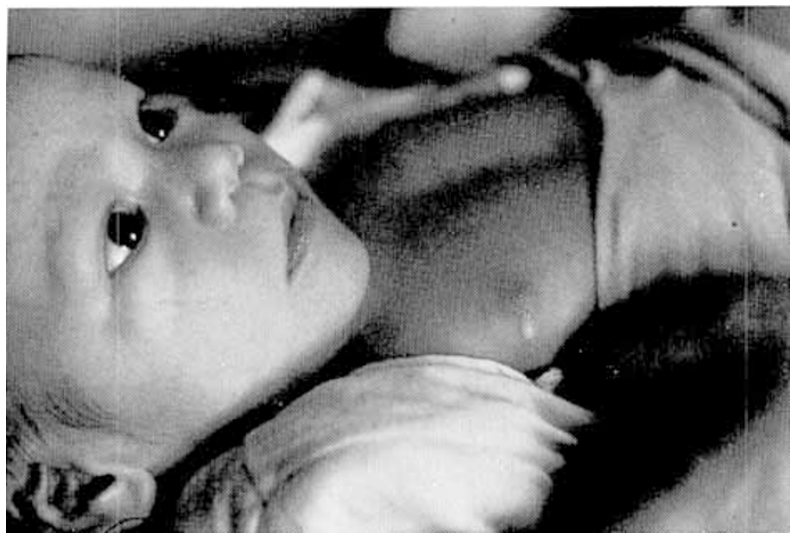

Fig. 1. Appearance of witch's milk at infant's nipple after manual expression.

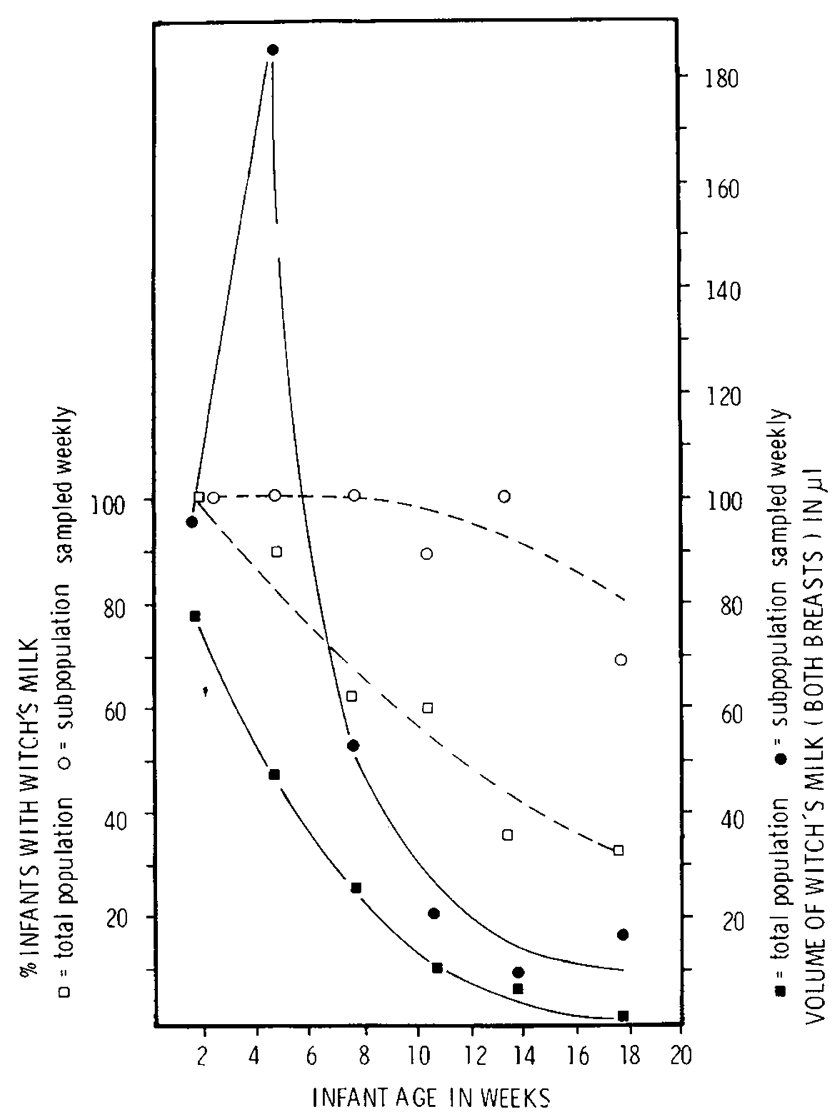

Fig. 2. Relationship of age to frequency of obtaining witch's milk specimens and the volume of the specimens.

edly was $1500 \mu \mathrm{l}$. The volume was not related to pressure of manual expression or sex, but was significantly related to age of the baby (Fig. 2), decreasing with increasing age. The subpopulation of infants sampled at weekly intervals consistently demonstrated a higher sample volume.

\section{DISCUSSION}

It was relatively easy to achieve a study population with infants of both sexes and many different ages represented. However, it was difficult to achieve substantial representation of non-Caucasian ethnic groups and bottle-fed babies. The esoteric nature of the project and ethical prerequisites of voluntary participation and informed consent, selected for well-educated parents who were of upper socioeconomic status, primarily Caucasian, and practiced breast feeding almost exclusively.

This study corroborated older studies $(3,4,11,12)$ in demon- strating production of witch's milk declined with increasing age of the infant, and that fluid was not usually present in babies older than 4 months. The $100 \%$ recovery of witch's milk from babies less than 4 wk old demonstrated here has not been shown before, and assures that during the neonatal period when screening tests and emergency diagnostic tests are most needed, witch's milk would be available. The increased frequency of obtaining specimens from the nine babies sampled repeatedly, implies continued production of milk by the infant over a period of several months, a possibility previously suggested by Dossett (6). Therefore, if witch's milk were used as a diagnostic specimen, repeated tests would be possible during the neonatal period.

Quantitative measurement of the volume of witch's milk and its relationship to age, sex, or pressure of manual expression have never been reported before. The median volume of $55 \mu \mathrm{l}$ obtainable from infants under $3 \mathrm{wk}$, is sufficient for bacterial cultures or microchemistry tests, which are performed using volumes ranging 10-100 $\mu \mathrm{l}$ (16). The extent to which microorganisms or chemical substances are secreted into witch's milk, is relatively unexplored; serum proteins being the only substances analyzed (23). That group found witch's milk contained lactoferrin and albumin but no detectable level of immunoglobulins. The number of chemical substances secreted into the breast fluids of adults has been extensively studied and is enormous, including minerals, amino acids, vitamins, fats, milk proteins, immunoglobulins and other serum proteins (14), iron (17), thyroxine (22), nicotine (19), and toxic industrial chemicals (21). Salmonella, Toxoplasma, and pathogenic strains of Escherichia coli have been found in the milk of mothers with systemic infections caused by these organisms (20). Therefore, based on the contents of adult milk, it is likely witch's milk contains many diagnostically useful substances.

This might be particularly important in the recognition of genetically determined metabolic diseases which can be prevented if treatment is started shortly after birth. Blood and urine specimens used for current neonatal screening tests, have worked well, but there are several disadvantages: (1) it is sometimes difficult to get enough blood from the standard heel stick, and with excessive squeezing, "tissue juice" dilutes the specimen resulting in incorrect test values. The heel stick is painful to the baby and infections have occasionaly resulted, some rarely leading to osteomyelitis and death (1). (2) Neonatal urine collection with a plastic bag, involves virtually no pain or risk of infection, but its time of availability is not predictable. Furthermore, the concentration of test substances depends on urine volume which is not constant, and is difficult to measure.

I have shown here that witch's milk is easy and virtually painless to obtain, and is present in $100 \%$ of infants $3 \mathrm{wk}$ of age or less at any moment they are sampled. Since its recovery is a noninvasive procedure, risk of infection is negligible. Although the volume is variable it can be easily and accurately measured and corrected for in expressing concentrations.

The next step for future studies on witch's milk would be to thoroughly analyze the chemistry and microbiology of witch's milk to determine if it expresses any substances of diagnostic usefulness. For example, the most widespread neonatal screening test, for phenylketonuria $(8,15)$, detects abnormal levels of phenylalanine in neonatal blood. The concentration of phenylalanine in milk from adult women $(64 \mathrm{mg} / \mathrm{dl})(14)$, however, is considerably higher than in blood $(<5.0 \mathrm{mg} / \mathrm{dl})(9)$. If witch's milk also expressed higher concentrations of phenylalanine than blood, the sensitivity of laboratory tests using phenylalanine as an indicator might be amplified if milk rather than blood were used as the test material. The use of witch's milk as an alternative body fluid to detect chemicals and microorganisms is a virgin field that deserves further investigation.

\section{REFERENCES AND NOTES}

1. Blumenfeld, T. A., Turi, G. K., and Blanc, W. A.: Recommended site and depth of newborn heel skin punctures based on anatomical measurements and histopathology. Lancet, I: 230 (1979).

2. Bohnius, J.: Circulus anatomico-physiologicus, seu oeconomica corporis animalis, Hoc est, cogitata, functionum animalum postissimarum formalitatem \& caucas 
concernentia. p. 30 (J. F. Gleditsch, Lipsiae, 1686).

3. Czerny, A.: Ueber die Brustdrüsensecretion beim Neugeborenen und über das Verhältniss der sogenannten Colostrumkörperchen zur Milchsecretion. Festschrift fuer Henoch. pp. 194-204 (Hirschwald Verlag, Berlin. 1890).

4. Dietrich, E. F.: Untersuchungen über das Verhalten der menschlichen Brustdrüse im ersten Lebensjahre. Virchows Archive., 264: 486 (1927).

5. HEW, Office of the Sec'y: Protection of human subjects: technical amendments. Federal Register., 40: 11854 (1975).

6. Dossett, J. A.: The nature of breast secretion in infancy. J. Pathol. Bact., 80: 93 (1960).

7. Forbes, T. R.: Witch's milk and witch's marks. Yale J. Biol. Med., 22: 219 (1950).

8. Guthrie, R. and Susi, A.: A simple phenylalanine method for detecting phenylketonuria in large populations of newborn infants. Pediatrics, 32: 338 (1963).

9. Henry, J. B.: Todd, Sanford, Davidsohn's Clinical Diagnosis and Management by Laboratory Methods. pp. 2083-2107 (W. B. Saunders Co., Philadelphia, PA, 16th edition, 1979).

10. Hiba J., del Pozo, E., Genazzani, A., Pusterla, E., Lancranjan, I., Sidiropoulos, D., and Gunti, J.: Hormonal mechanism of milk secretion in the newborn. J. Clin. Endocrin. Metab., 44: 973 (1977).

11. Jaroschka, K.: Ein Beitrag zur Kenntnis der Sekretionsvorgänge der Brustdrüse von Säuglingen. Monatschrift fuer Kinderheilkunde, 45: 523 (1929).

12. Lindig, P.: Die Brustdrüsensecretion beim Neugeborenen. Monatschrift fuer Geburtsheilkunde und Gynekologie, 47: 534 (1918).

13. Lyons, W. R.: The hormonal basis for "witch's milk." Proc. Soc. Exp. Biol., 37: 207 (1937).

14. Macy, I. G. and Kelly, H. J.: Human milk and cow's milk in infant nutrition. In: S. K. Kon and A. T. Cowie. Milk: The mammary gland and its secretion. Vol II, pp. 265-304 (Academic Press, New York, NY, 1961).

15. Mamunes, P.: Neonatal screening tests. In: J. F. Nicholson, B. M. Wagner: Symposium on the Laboratory in Pediatric Practice. Pediatr. Clin. of N. Amer.

\section{7: 733 (1980).}

16. Mattenheimer. H.: Micromethods for the clinical and biochemical laboratory. Chapter 1 (Ann Arbor Science Publishers, Ann Arbor, MI. 1970).

17. McMillan, J. A., Landaw, S. A., and Oski, F. A.: Iron sufficiency in breast-fed infants and the availability of iron from human milk. Pediatrics, 58: 686 (1976).

18. Nelson, W. E.: Textbook of Pediatrics. p. 392 (W. B. Saunders Co., Philadelphia. PA, 1979).

19. Petrakis, N. L., Gruenke, L. D., Beelen, T. C., Castagnoli, N., Jr., and Craig, J. C.: Nicotine in the breast fluid of nonlactating women. Science, 199: 303 (1978).

20. Remington, J. S. and Klein J. O.: Infectious Diseases of the Fetus and Newborn Infant. pp. 219-220, 909, 1006 (W. B. Saunders, Co., Philadelphia, PA, 1976).

21. Rogan, W. J. Bagniewska, M. A., and Damstra, T.: Pollutants in breast milk, New Engl. J. Med., 302: 1450 (1980).

22. Sack, J., Amado, O., and Lunenfeld, B.: Thyroxin concentration in human milk. J. Clin, Endocrinol. Metab.. 45: 171 (1977).

23. Wiersbitzky, S. and Weyrauch, P-Ch.: Die Serumproteine des Brustdrüsensekretes bei menschlichen Neugeborenen. Acta. Biol. Med. Germ., 24: 911 (1970).

24. The author is grateful to Elsie Joe-Rie for technical help. I thank Thomas Jenewein for graphic arts and Sharon Long for photography. I am indebted to the following for supplying names of parents of prospective subjects: Bobbie Gould (La Leche League - Berkeley Chapter), Andrea Gronsky (La Leche League - El Cerrito Chapter), Marge Freeman, Jean Revere, and Jacque Minz.

25. Requests for reprints should be addressed to: Dr. Gertrude C. Buehring, School of Public Health, University of California, Berkley, CA 94720.

26. This research was supported by the following University of California, Berkeley funds: Committee on Research Faculty Grants, Grossman Endowment to the School of Public Health, and DHEW Biomedical Sciences Grant S07RR05467. 27. Received for publication July 2, 1981.

28. Accepted for publication November 11, 1981. 